\title{
PERUBAHAN FONOLOGI \\ DALAM BAHASA DUANO DAN BAHASA MELAYU
}

(PHONOLOGICAL CHANGES OF THE DUANO AND MALAY LANGUAGES)

\author{
Nur Fathiha Asyikin Baharin \\ fathihasyikin@yahoo.com \\ Rohani Mohd Yusof \\ romy@um.edu.my \\ Noor Hasnoor Mohamad Nor \\ hasnor@um.edu.my \\ Akademi Pengajian Melayu \\ Universiti Malaya, Kuala Lumpur \\ Malaysia
}

Received: 1st September 2021; Accepted: 4th October 2021;

Published: 26th October 2021

\begin{abstract}
The Orang Asli, who are considered minorities in Malaysia, is divided into three groupsthe Negrito, Senoi and Proto-Malays. Each group has its language used during oral communication. The Duano language is one of the indigenous languages under the ProtoMalay group. The language is classified under the Austronesian family of languages, similar to the Malay language. The Duano language is the language of the indigenous people who dwell in the state of Johor. Based on the scale presented by EGIDS in "Ethnologue" (2021), the Duano language is at risk of becoming moribund. Researchers also found that deep comparative studies of the phonological systems to be limited. Hence, this paper aims to examine the process of phonological changes in the Duano language by comparing it with the Standard Malay Language (BMS). This study utilises the upstream fieldwork approach, supported by conducting interviews, observations, recordings and note-taking. The structural theory was applied during analysis, whereby the Duano and BMS cognates were transcribed phonemically and classified under specific sub-systems. They were then analysed using a qualitative comparative perspective to examine the phonological differences that had occurred. Results showed that the Duano language had undergone phonological changes, such as phoneme alignment, glottalisation, monophthongisation and delineation. In conclusion, the phonological changes indicated an independent evolutionary process for both languages in a particular environment, eventually forming a distinct phonological innovation.
\end{abstract}

Keywords: indigenous, Duano, comparative study, phonology, sound change, innovation. 


\begin{abstract}
Abstrak
Orang Asli merupakan golongan minoriti di Malaysia yang dibahagikan kepada tiga kelompok utama secara pentadbiran, iaitu Negrito, Senoi dan Melayu-Proto. Setiap kelompok mempunyai bahasa tersendiri yang digunakan untuk berkomunikasi secara lisan. Bahasa Duano ialah salah satu bahasa orang Asli daripada kelompok MelayuProto. Bahasa Duano tergolong dalam kelompok bahasa rumpun Austronesia sama seperti bahasa Melayu. Tumpuan masyarakat dan bahasa Duano adalah di negeri Johor. Skala Expanded Grade Intergenerational Disruption Scale EGIDS yang dikemukakan dalam Ethnologue (2021) menunjukkan bahawa bahasa Duano adalah bahasa yang semakin pupus (bahasa moribund). Kajian perbandingan sistem fonologi secara intensif didapati amat terhad. Justeru, makalah ini bertujuan untuk meneliti proses-proses perubahan fonologi yang berlaku dalam bahasa Duano melalui perbandingan dengan bahasa Melayu Standard (BMS). Kajian ini menggunakan kaedah lapangan huluan melalui teknik temubual, pemerhatian, rakaman, serta catatan. Teori struktural digunakan dalam analisis kajian yang dijalankan. Kata berkognat bahasa Duano dan BMS ditranskripsi secara fonemik, diklasifikasikan mengikut subsistem tertentu dan dianalisis menerusi perspektif perbandingan kualitatif bagi membandingkan perbezaan fonologi yang berlaku. Hasil kajian menunjukkan bahasa Duano mengalami proses perubahan fonologi seperti kesejajaran fonem, pengglotisan, pemonoftongan, penyahnasalan dan sebagainya. Gejala perbezaan fonologi yang berlaku antara bahasa Duano dan BMS menunjukkan berlakunya proses evolusi secara bersendirian bagi kedua-dua bahasa sekeluarga tersebut dalam persekitaran tertentu yang akhirnya membentuk inovasi fonologi yang tersendiri.
\end{abstract}

Kata Kunci: Orang Asli, Duano, kajian perbandingan, fonologi, perubahan bunyi, inovasi.

\title{
Pengenalan
}

Orang Duano merupakan kumpulan orang Asli yang tergolong dalam kelompok orang Asli Melayu-Proto. Kelompok Melayu-Proto, yang turut dikenali sebagai Melayu-Tua dan Melayu-Purba dikatakan telah berhijrah dari daerah Yunnan dan mendiami kawasankawasan tertentu di Asia Tenggara (Najjah Salwa Abd Razak \& Wan Norhasniah Haji Wan Husin, 2011, p.208). Orang Duano yang juga dikenali sebagai "Orang Kuala" atau "Desin Dolaq" boleh ditemui di daerah-daerah tertentu negeri Johor yang terletak di sepanjang pantai barat Johor menghadap Selat Melaka, iaitu Batu Pahat, Pontian dan Kota Tinggi (Mohd Sharifudin Yusof, 2013, p.22). Orang Duano dikatakan berasal dari beberapa buah pulau yang terletak di kepulauan Riau-Lingga (Sopher, 1965). Kehadiran kumpulan ini ke Johor tidak dapat ditentukan secara tepat memandangkan mereka sememangnya telah sedia ada bergerak bebas di seluruh pelosok Nusantara sebelum pemisahan Indonesia dan Malaysia (Mohd Sharifudin Yusop, 2013, p.20). Tambahnya lagi, sebahagian orang Duano telah singgah dan menetap di Johor sejak dahulu lagi sebelum kehadiran kelompok seterusnya secara besar-besaran sekitar 50 tahun pertama abad ke-20. Selain itu, orang Duano juga dikatakan sudah bermastautin di Temasik dan Melaka sebelum kedatangan Parameswara (Andaya, 1987). Kajian-kajian terdahulu mendapati bahawa orang Duano telah memainkan peranan penting semasa era kesultanan 
Melayu Melaka dan Kesultanan Johor-Riau sebagai pengawal pantai, pendayung dan orang perutusan kerajaan.

Orang Duano mempunyai persamaan yang agak ketara dengan kaum Melayu, iaitu daripada segi fizikal, cara berpakaian, adat tradisi dan amalan beragama. Bentuk persamaan ini dapat dikatakan sebagai warisan pengekalan bersama daripada generasi terdahulu. Menurut Habibah Abdul Jabbar, Nor Azlin Hamidon, Muhammad Ismail Ab Kadir dan Abdul Razak Abdul Jabbar (2019, p. 69), antara aspek yang sering diadaptasi adalah dari segi kegiatan ekonomi, politik, sosiobudaya dan hubungan perkahwinan. Titik perbezaan antara orang Duano dan kaum Melayu hanya dapat ditentukan berdasarkan kawasan penempatan orang Duano yang kebanyakannya terletak di kawasan pedalaman dan rizab orang Asli serta bahasa pertuturan, iaitu bahasa Duano. Walau bagaimanapun, bahasa Duano kini sudah pun bertaraf bahasa moribund memandangkan bahasa ini sudah hampir ke arah kepupusan dan hanya dituturkan oleh golongan tertentu dalam bilangan yang sangat kecil, iaitu oleh warga emas sahaja. Statistik kependudukan orang Duano khususnya di Johor semakin meningkat, iaitu dianggarkan seramai 3454 orang namun kadar penggunaan bahasa Duano amat rendah (JAKOA, 2018). Tambahan lagi, bahasa ini juga sudah menjadi asing bagi golongan muda Duano memandangkan mereka telah berasimilasi dan menggunakan bahasa Melayu sepenuhnya. Golongan muda bukan sahaja tidak mampu bertutur menggunakan bahasa Duano, bahkan mereka langsung tidak boleh memahami kosa kata yang digunakan oleh golongan tua. Di samping itu, bahasa Duano tidak lagi berfungsi sebagai bahasa pertama, sebaliknya fungsi tersebut telah diambil alih oleh bahasa Melayu. Justeru, bahasa Duano yang masih bertahan sehingga ke hari ini hanya digunakan oleh kelompok tertentu dalam konteks perbualan seharian dan kegiatan ekonomi sahaja. Situasi yang hampir serupa juga dapat dilihat menerusi penggunaan bahasa Melayu oleh penutur Melayu di Nakhon Si Tammarat (Ligor). Majoriti masyarakat di Melayu di kawasan tersebut mulai berasimilasi dengan bahasa Thailand. Kemampuan pertuturan bahasa Melayu mereka amat rendah, terutamanya golongan remaja. Hal ini dipengaruhi oleh nilai ekonomi bahasa Melayu dan dasar penggunaan bahasa di Thailand yang mendiskriminasi bahasa-bahasa lain (Ab. Razak Ab Karim \& Muhammad Saiful Haq Hussin, 2011).

Bahasa Duano merupakan bahasa yang diturunkan daripada induk Melayu-Proto yang turut menjadi "ibu” kepada bahasa Melayu (Rohani Mohd Yusof \& Noor Hasnoor Mohamad Nor, 2015). Penurunan bahasa turunan daripada bahasa induk akan memperlihatkan unsur retensi dan inovasi (Mohd Tarmizi Hasrah, Shahidi A.H \& Rahim Aman, 2013). Kewujudan unsur retensi ialah pengekalan hasil warisan bersama, iaitu persamaan unsur dan ciri bahasa yang begitu banyak jumlahnya sehingga tidak mungkin dikatakan sebagai hasil pinjaman (Asmah Haji Omar, 1991, p. 45). Bentuk-bentuk persamaan tersebut boleh dilihat menerusi ciri fonologi dan kata berkognat yang terdapat pada kata leksikal kedua-dua bahasa. Ciri inovasi pula ialah bentuk-bentuk perubahan yang dialami oleh bahasa turunan setelah berpisah daripada induknya dan berkembang secara sendirian dalam persekitaran yang tersendiri.

Ciri inovasi merupakan bentuk-bentuk baharu sistem bahasa yang terhasil melalui proses perubahan bahasa. Perubahan bahasa merupakan fenomena universal yang akan berlaku dalam setiap bahasa di dunia seiring dengan perkembangan peradaban manusia. Menurut Rohani Mohd Yusof (1986), perubahan bahasa berlaku seiring dengan faktor masa dan perkembangan yang dilalui masyarakat yang kemudiannya 
menyebabkan perubahan pada struktur bahasa. Selain itu, Herbert Schendl (2001, p. 16) juga berpendapat bahawa perubahan bahasa turut dipengaruhi oleh beberapa faktor lain seperti: "... they have evolved in the course of centuries as a result of geographical distance and isolation, social factors and political development, and through contact with other languages".

Asmah Haji Omar (1991, p.46) pula berpendapat bahawa perubahan bahasa sememangnya telah terbentuk melalui perbezaan pertuturan individu dalam sesebuah kawasan asal yang sama. Perbezaan tersebut akan menjadi ketara apabila penuturnya bermigrasi ke kawasan lain. Perbezaan yang seawalnya kecil akan menjadi mengalami peluasan dan seterusnya membentuk ciri bahasa baharu yang berbeza dengan bahasa induk. Pendapat ini juga boleh disokong dengan kenyataan R. L Trask (1996) yang menyatakan bahawa bahasa sebenarnya sentiasa berubah dari sehari ke sehari, terutamanya dari segi bentuk pengucapan. Hal ini kerana, bahasa sebagai objek budaya amat dipengaruhi oleh perkembangan penuturnya. Misalnya, bahasa yang dituturkan pada zaman dahulu sememangnya amat berbeza dengan variasi bahasa yang wujud pada hari ini. Bahkan, bentuk bahasa yang digunakan pada hari ini juga berkemungkinan berbeza dengan bentuk bahasa yang digunakan pada tahun lepas yang banyak dipengaruhi oleh perkembangan teknologi dan budaya. Sebagai contoh, bahasa Melayu sendiri telah melalui perkembangan yang amat panjang dimulai dengan bahasa Melayu Kuno, bahasa Melayu Klasik dan bahasa Melayu Moden yang sentiasa dikemas kini sehingga ke hari ini. Setiap peringkat perkembangan bahasa yang dinyatakan tersebut ditandai dengan ciriciri tersendiri yang sesuai dengan budaya di ketika itu. Sila perhatikan kenyataan R.L Trask (1996, p. 12) berikut: "Every language that is spoken continues to change, not just century by century, but day by day. The language that you speak is not just different from your parents 'language, it's different from the language you were speaking last year or last week, even if you don't notice change occurring on such a small time-scale". Jadi bahasa-bahasa tersebut akan berkembang dan membentuk ciri baharu mengikut persekitaran tersendiri yang berbeza dengan bentuk bahasa induknya.

Perubahan bahasa merangkumi perubahan ciri dan bentuk sistem-sistem bahasa, iaitu bunyi, kata, nahu dan makna. Bentuk perubahan yang akan dibandingkan ialah perubahan yang berlaku secara tetap, teratur dan berulang-ulang dalam perkataan yang mempunyai pola serupa (Noriah Mohamed, 1996, p. 134). Makalah ini akan meneliti bentuk-bentuk perubahan yang berlaku dalam sistem bunyi bahasa Duano dan BMS. Perubahan bunyi merupakan penghilangan ciri-ciri distingtif tertentu bagi sesuatu bunyi dan penggantiannya dengan ciri distingtif lain (Asmah Haji Omar, 1995, p. 26). Jadi makalah ini akan meneliti kata berkognat bahasa Duano dan BMS bagi menilai sebarang bentuk perubahan fonologi yang terbentuk sepanjang tempoh perkembangan dalam persekitaran tersendiri. Selain itu, perbandingan umum juga akan dijalankan terhadap dialek-dialek Melayu dan bahasa Austronesia tertentu sekiranya bersepadanan dengan bahasa Duano.

\section{Metodologi Kajian}

Hubungan kekeluargaan dan perkaitan antara bahasa dapat ditentukan melalui dua kaedah utama dalam bidang linguistik bandingan, iaitu melalui kaedah perbandingan 
sistem dan struktur bahasa (kualitatif) serta kaedah leksikostatistik (kuantitatif) (Asmah Haji Omar, 2018, p. 67). Walau bagaimanapun, kajian ini mengaplikasikan kaedah lapangan huluan pendekatan kualitatif dengan bersumberkan data primer dalam bentuk lisan yang diperolehi secara terus melalui informan. Menurut Asmah Haji Omar (2001, p. 60), terdapat tiga aspek penting yang perlu diambil kira dalam sesuatu kajian lapangan yang akan mempengaruhi kualiti dan nilai autentik data, iaitu pemilihan informan, proses pengumpulan data dan proses analisis data.

Kajian ini telah menemu bual enam orang informan dalam lingkungan umur 5075 tahun. Kesemua informan merupakan penduduk tetap di penempatan rizab Orang Asli Duano Kampung Baru Kuala Benut. Kesemua informan tersebut mempunyai tahap kesihatan dan organ pertuturan yang baik bagi memastikan data yang dikumpulkan tepat penyebutannya. Data dikumpulkan melalui kaedah rakaman tersembunyi. Pengkaji terlebih dahulu telah menyediakan senarai perkataan yang terdiri daripada pelbagai domain seperti domain perbuatan, kata sifat, tumbuh-tumbuhan, komponen rumah, anggota badan dan sebagainya. Senarai perkataan tersebut juga tidak dihadkan jumlahnya bagi memastikan data yang dikumpulkan bersifat representatif. Informan perlu menyebut kembali perkataan tersebut dalam bahasa Duano. Rakaman juga akan dijalankan ketika informan berbual sesama sendiri dan bercerita tentang topik-topik tertentu yang dikemukakan pengkaji bagi mendapatkan gaya penyebutan dan pertuturan yang lebih neutral dan tidak dibuat-buat. Bagi proses analisis data, rakaman tersebut akan ditranskripsikan secara fonemik dan diklasifikasikan berdasarkan subsistem tertentu. Proses perbandingan akan dilakukan bagi meneliti sebarang bentuk perubahan bunyi yang berlaku antara kata berkognat bahasa Duano dan bahasa Melayu. Kaedah ini turut dikenali sebagai kaedah pemeriksaan unsur retensi dan inovasi, iaitu kajian yang bertujuan untuk membandingkan kata berkognat bahasa berkerabat bagi mengenal pasti bentuk-bentuk perubahan unsur bahasa (Noriah Mohamed, 1999). Data-data tersebut akan dikelompokkan berdasarkan persamaan proses perubahan seperti proses pemonoftongan, perangkapan, peleburan dan sebagainya.

\section{Sorotan Kajian}

Penyelidikan dan penelitian terhadap orang Asli Duano telah bermula sejak abad ke-19 yang dipelopori oleh para sarjana Barat seperti Favre (1865), Skeat dan Blagden (1906), Raffles (1949), Sopher (1972) dan Carey (1972). Kajian-kajian tersebut merujuk orang Duano sebagai "Orang Laut", "Orang Kuala", "Jakun", dan "Jakun Laut". Kajian-kajian tersebut juga berfokus kepada bidang sosiobudaya seperti latar belakang, asal usul, cara hidup, budaya, agama dan kegiatan ekonomi (Mohd Sharifudin Yusop, 2013, p. 15). Kesemua kajian berkenaan orang Duano pada era tersebut ialah kajian berbentuk bukan linguistik. Kajian berbentuk linguistik amat terhad dan hanya tertumpu kepada aspek pengumpulan dan pendeskripsian kosa kata sahaja, misalnya menerusi Raffles (1949) yang mendokumentasikan kosa kata asas bahasa Duano. Hal ini juga disokong oleh Norazila bte Alias (1986) yang berpendapat bahawa kajian- kajian terdahulu yang dijalankan oleh pengkaji Barat lebih menjurus ke arah penyenaraian kosa kata untuk memenuhi keperluan pentadbiran Barat, bukanlah kajian yang mengaplikasikan pengkaedahan linguistik, apatah lagi kajian berbentuk perbandingan. 
Kajian perbandingan bahasa Duano mula diusahakan pada tahun 1920-an khususnya oleh para pengkaji tempatan. Antara kajian terawal adalah menerusi Yuszaidy Mohd Yusoff, Mohamad Nazri Ahmad dan Mohamed Anwar Omar Din (2009) yang mendapati bahawa sebahagian besar kosa kata bahasa Duano adalah berkognat dengan bahasa Melayu. Perbezaan linguistik yang wujud dikenali sebagai pengubahsuaian fonetik misalnya "matu" = mata, "royu" = kayu dan "sayu" = sungai. Walau bagaimanapun, kajian ini tidak bertujuan untuk membandingkan sistem bahasa Duano, namun kajian ini bertemakan sosiobudaya yang meneliti latar belakang, penempatan, kegiatan ekonomi, kepercayaan dan adat tradisi masyarakat Duano. Kajian ini hanya menyentuh aspek bahasa sebagai salah satu daripada komponen budaya masyarakat Duano.

Kajian lain menerusi Mohd Sharifudin Yusop (2013) merupakan kajian sosiolinguistik yang terbahagi kepada dua bahagian, iaitu bahagian pertama adalah pendeskripsian kosa kata dan sistem fonologi bahasa Duano. Bahagian kedua pula meliputi pemilihan dan sikap penutur terhadap bahasa. Walau bagaimanapun, kajian ini hanya mendeskripsi sistem fonologi bahasa Duano secara umum, iaitu penyenaraian terhadap subsistem vokal, konsonan dan rangkap vokal sahaja. Dari sudut perbandingan, kajian ini hanya membandingkan sistem fonologi bahasa Duano dengan bahasa Melayu secara umum, misalnya daripada segi jumlah dan kehadiran fonem dalam lingkungan perkataan. Kajian ini boleh dikategorikan sebagai asas dan permulaan kajian yang menyentuh tentang aspek perbandingan terhadap bahasa Duano. Namun, penelitian yang lebih mendalam dan menyeluruh terhadap perbandingan sistem fonologi bahasa Duano perlu dilakukan dalam kajian akan datang.

Kajian oleh Rohani Mohd Yusof dan Noor Hasnoor Mohamad Nor (2014) pula bertujuan untuk membandingkan tahap kekerabatan bahasa-bahasa Orang Asli kelompok Melayu-Proto dan bahasa Melayu. Hasil kajian ini mendapati bahawa bahasa Duano dan bahasa Melayu bertaraf bahasa sekeluarga dengan peratus persamaan kata berkognat sebanyak $80.9 \%$. Walau bagaimanapun, kajian ini tidak membandingkan bahasa Duano dengan bahasa Melayu secara mendalam dan data yang digunakan agak terhad, iaitu sebanyak 100 kosa kata sahaja dengan pengkaedahan kuantitatif. Jadi, kajian lanjutan perlu dijalankan dengan mengaplikasikan kaedah kualitatif dan jumlah data yang lebih besar jumlahnya.

Rohani Mohd Yusof dan Nur Hidayah Mohamed Suleiman $(2011,2014)$ pula membandingkan sistem bilangan bahasa Duano berdasarkan kawasan penempatan yang berbeza. Kajian ini turut membandingkan sistem bilangan bahasa Duano dan bahasa Melayu. Dapatan menunjukkan bahawa sistem bilangan bahasa Duano mempunyai perbezaan dengan bahasa Melayu, namun ia tidak begitu dominan. Perbezaan tersebut boleh dilihat berdasarkan penggunaan perkataan dan istilah tertentu dalam bahasa Duano bagi merujuk kata bilangan seperti "nombo" yang menggantikan imbuhan "ke-" dalam bahasa Melayu dan "siko?" yang menggantikan perkataan "pertama". Perbezaan lain juga dapat dilihat menerusi perbezaan bunyi seperti /duw u/, /tigu/, /əmpət/ dan sebagainya. Pengkaji juga menyatakan bahawa persamaan sistem bilangan antara bahasa Duano dan bahasa Melayu disebabkan faktor kekerabatan dan asimilasi penutur.

Nur Hidayah Mohamed Suleiman (2015) menerusi "Struktur Frasa Bahasa Orang Asli Duano" merupakan kajian linguistik deskriptif yang bertujuan untuk meneliti penggolongan frasa bahasa Duano dan mengenal pasti struktur frasa selapis dan kompleks 
bahasa Duano. Selain itu, kajian ini juga meneliti frasa berdasarkan fungsi penggunaannya dalam ayat. Hal ini memandangkan terdapat frasa yang tidak berfungsi dalam golongan yang sama, sebaliknya ia berfungsi dalam golongan frasa lain. Kajian ini merupakan kajian lapangan huluan yang dijalankan di Kampung Bumiputera Dalam, Rengit, Johor. Selain itu, kajian ini juga menggunakan pendekatan struktural bagi meneliti struktur sintaksis bahasa Duano dengan pemerincian terhadap bentuk frasa bahasa Duano. Walau bagaimanapun, kajian ini didapati sedikit sebanyak turut membandingkan struktur frasa bahasa Duano dan bahasa Melayu. Dapatan kajian menunjukkan bahawa bahasa Duano mempunyai golongan kata yang sama dengan bahasa Melayu. Seterusnya, golongan frasa bahasa Duano juga memperlihatkan kesejajaran dengan bahasa Melayu, iaitu terdiri daripada frasa namaan, frasa kerja, frasa adjektif serta adverba. Dari segi binaan frasa pula, frasa bahasa Duano dimulai dengan inti dan diikuti dengan keterangan yang mirip dengan binaan frasa bahasa Melayu. Dapatan tersebut merumuskan bahawa kedua-dua bahasa mempunyai golongan frasa dan binaan frasa yang sama. Hal ini menunjukkan bahawa kedua-dua bahasa tersebut diturunkan daripada induk yang sama dan masih mengekalkan ciri kekerabatan tersebut sungguhpun telah berkembang mengikut peredaran zaman. Kajian ini turut menekankan bahawa kesejajaran tersebut turut dipengaruhi oleh asimilasi kaum Orang Asli Duano dengan masyarakat Melayu.

Asmah Haji Omar, Samsur Rijal Yahya dan Noor Hasnoor Mohamad Nor (2018) menerusi "The Orang Asli of Malaysia: A Linguistic Perspective" merupakan kajian yang mendeskripsi latar belakang dan etnolinguistik kelompok orang Asli di Malaysia. Di samping itu, fokus utama kajian ini juga adalah untuk membandingkan sistem dan struktur serta kekerabatan bahasa-bahasa orang Asli dalam rumpun Austronesia dan Austroasia. Dari segi perbandingan, kajian ini membahagikan perbandingan bahasa orang Asli Austronesia kepada dua, iaitu perbandingan kuantitatif (leksikostatistik) dan perbandingan sistem bahasa (fonologi). Kajian ini telah membandingkan kata berkognat Duano dan bahasa Melayu dengan menggunakan 100 kosa kata Swadesh. Dapatan menunjukkan bahawa peratusan kekerabatan di antara kedua-dua bahasa adalah sebanyak 69\% dan peratusan tersebut menunjukkan bahasa Duano dan bahasa Melayu adalah dua bahasa yang berbeza dari suatu bahasa induk yang sama, iaitu bahasa induk Melayu-Proto. Bagi perbandingan sistem fonologi pula, kajian ini hanya membandingkan sistem fonologi dialek-dialek Orang Asli Melayu-Proto secara umum, yang terdiri daripada dialek Jakun, Temuan, Kanak dan Seletar. Bahasa Duano tidak terlibat dalam perbandingan tersebut memandangkan tarafnya yang berstatus bahasa yang berbeza.

\section{Analisis dan Dapatan Kajian}

Kajian ini mendapati bahawa perkembangan bahasa Duano setelah terpisah daripada bentuk induknya telah mewujudkan bentuk inovasi, iaitu perbezaan sistem fonologi tersendiri yang universal dan berbeza daripada BMS. Inovasi fonologi tersebut boleh berlaku dalam subsistem vokal, diftong, konsonan dan rangkap vokal. Penelitian juga menunjukkan bentuk perbezaan yang berlaku dalam sesuatu kata juga boleh wujud secara bertumpang-tindih. Gejala tersebut turut dikenali sebagai tertib rumus atau "ordering of rules" yang memerlukan suatu proses berlaku terlebih dahulu dalam suatu perkataan sebelum proses lain (Asmah Haji Omar, 1995, p. 33). Hasil kajian mendapati bahawa bentuk perbezaan dan perubahan fonologi bahasa Duano terdiri daripada proses 
kesejajaran fonem, penyahnasalan, pengglotisan, perangkapan, pemonoftongan, penghilangan suku kata, peleburan fonem dan metatesis.

\section{Kesejajaran Fonem}

Kesejajaran fonem merupakan proses penggantian ciri distingtif fonem antara dua bahasa berbeza dalam lingkungan perkataan yang sama tanpa melibatkan perubahan bentuk dan makna (Rohani Mohd Yusof, 2016, p. 92). Kesejajaran fonem boleh berlaku dalam sistem vokal dan konsonan.

\section{a) Kesejajaran Vokal}

Kesejajaran vokal antara bahasa Duano dan bahasa Melayu dapat dilihat menerusi padanan vokal seperti berikut:

Jadual 1: Kesejajaran Vokal/ə/: /a/

\begin{tabular}{|l|l|}
\hline Bahasa Duano & BMS \\
\hline$/ \mathrm{a} /$ & $/ \mathrm{a} /$ \\
\hline$/ \mathrm{u} /$ & $/ \mathrm{a} /$ \\
\hline$/ \mathrm{o} /$ & $/ \mathrm{u} /$ \\
\hline$/ \mathrm{u} /$ & $/ \mathrm{i} /$ \\
\hline
\end{tabular}

\section{i) Kesejajaran Vokal /ə/ : /a/}

Kesejajaran vokal /ə/ bahasa Duano dan vokal /a/ BMS berlaku dalam lingkungan suku kata pertama /KV-/ dan suku kata akhir /-KVK/. Vokal tengah /a/ dan /a/ tidak memperlihatkan perubahan fitur distingtif yang ketara memandangkan kedua-duanya berada dalam subsistem vokal tengah. Walau bagaimanapun, perbezaan antara keduanya dapat dilihat dari segi ketinggian lidah sewaktu penghasilannya, iaitu:

Jadual 2: Fitur Distingtif Vokal /ə/: /a/

\begin{tabular}{|c|c|}
\hline /ə/ & $/ \mathrm{a} /$ \\
+tengah & + tengah \\
+tengah & + separuh luas \\
\hline
\end{tabular}

Menurut Asmah Haji Omar (2018, p. 145), vokal /ə/ dihasilkan dengan kedudukan lidah dan tahap ketinggian lidah berada di tengah-tengah, iaitu tidak sebaris dengan kedudukan lidah sewaktu penghasilan vokal /e/ dan /o/. Vokal /a/ pula dihasilkan pada kedudukan tengah lidah tetapi ketinggian lidah terletak separas dengan keadaan lidah sewaktu penghasilan vokal separuh luas. Di samping itu, bentuk kesejajaran ini juga merupakan antara bentuk perbezaan yang paling ketara dalam bahasa Duano kerana 
rata-rata vokal /a/ bahasa Duano akan menempati posisi vokal /a/ BMS. Bentuk perubahan ini merupakan ciri bunyi yang signifikan bagi bahasa Duano dan berfungsi seolah-olah sebagai identiti sistem fonologi bahasa Duano. Hal ini kerana rata-rata perkataan yang ditempati dengan vokal /a/ dalam BMS akan digantikan dengan vokal/ə/ dalam bahasa Duano. Selain itu, kesejajaran antara vokal /o dan /a/ dapat dilihat pada lingkungan tengah kata, iaitu bagi struktur [-KV-] dan [-KVK-]. Berikut merupakan antara contohnya:

Jadual 3: Contoh Kesejajaran Vokal /a/ : /a/

\begin{tabular}{|c|c|}
\hline Bahasa Duano & BMS \\
\hline /ə/ & /a/ \\
+ tengah & + tengah \\
+ tengah & + separuh luas \\
\hline /bəyu/ & bahu \\
$/$ bəbi/ & babi \\
$/$ dəgu/ & dagu \\
$/$ yapət/ & rapat \\
$/$ lambət/ & lambat \\
/pantəs/ & pantas \\
\hline
\end{tabular}

Situasi ini juga dapat dilihat dalam sesetengah dialek Melayu yang cenderung untuk menggantikan fonem /a/ dengan fonem /ə/. Antara dialek tersebut ialah dialek Melaka, dialek Johor dan dialek Selangor. Walau bagaimanapun, kesejajaran fonem /a/ dan /ə/ dalam dialek-dialek tersebut hanya hadir dalam lingkungan akhir kata sahaja dan dikenali sebagai kelainan pepet (Asmah Omar, 2008, p. 163). Antara contohnya adalah melalui perkataan /sayə/, /apə/, /kənə/ dan sebagainya.

\section{ii) Kesejajaran Vokal /u/ : /a/}

Kesejajaran vokal /u/ bahasa Duano dengan vokal /a/ BMS pula berlaku dalam lingkungan akhir kata sahaja, iaitu pada struktur /-KVK/ dan /-KV/. Sungguhpun keduadua vokal ini memperlihatkan perbezaan fitur distingtif yang ketara bagi kedua-dua bahasa, namun masih memperlihatkan kesejajaran terutamanya dari segi kedudukan fonem dalam lingkungan kata. Sila perhatikan antara contoh berikut:

Jadual 4: Contoh kesejajaran Vokal /u/ : /a/

\begin{tabular}{|c|c|}
\hline Bahasa Duano & BMS \\
\hline /u/ & /a/ \\
+ belakang & + tengah \\
+ sempit & + separuh luas \\
\hline$/$ tuluy/ & tulang \\
/kəyəygu/ & kerengga \\
/ayum/ & ayam \\
/sinu/ & singa \\
$/$ kudu/ & kuda \\
$/$ dədu/ & dada \\
\hline
\end{tabular}




\section{iii) Kesejajaran Vokal /o/ : /u/}

Kesejajaran antara vokal belakang /o/ bahasa Duano dengan vokal /u/ BMS pula memperlihatkan perubahan ciri distingtif, iaitu ciri vokal sempit berubah menjadi ciri vokal separuh luas.

Jadual 5: Fitur Distingtif Vokal /o/ : /u/

\begin{tabular}{|c|c|}
\hline Bahasa Duano & BMS \\
$/ \mathrm{o} /$ & $/ \mathrm{u} /$ \\
+belakang & +belakang \\
+separuh luas & +sempit \\
\hline
\end{tabular}

Walau bagaimanapun, kesejajaran ini boleh dianggap sebagai suatu variasi pengucapan bagi penutur Duano memandangkan dalam kebanyakan situasi, vokal /u/ masih dikekalkan dalam pengucapan. Berdasarkan data kajian, didapati informan turut menggunakan vokal /u/ dalam pengucapan dengan mengekalkan ciri sempit vokal /u/ tersebut. Misalnya:

Jadual 6: Contoh Pengekalan Ciri Vokal Sempit Bahasa Duano dan Bahasa Melayu
\begin{tabular}{|c|c|}
\hline Bahasa Duano & BMS \\
\hline /pukul/ & pukul \\
/səmut/ & semut \\
/tiyup/ & tiup \\
/buykus/ & bungkus \\
\hline
\end{tabular}

Jadi, situasi tersebut memperlihatkan kewujudan dua variasi penggunaan vokal /u/ dalam bahasa Duano. Variasi pertama adalah bentuk persamaan yang mengekalkan penggunaan vokal /u/ dalam kata berkognat bahasa Duano dan BMS. Variasi kedua pula memperlihatkan ciri perbezaan, iaitu penggantian vokal /o/ dalam bahasa Duano bagi posisi vokal /u/. Dari segi fonologi, bentuk perbezaan antara vokal /u/ dan /o/ adalah sangat kecil dan sering bervariasi antara sesuatu bahasa. Pemilihan vokal /o/ dalam sesetengah kata bahasa Duano berbanding /u/ dalam BMS dan bukan sebaliknya adalah bersifat alamiah kerana vokal /o/ lebih mudah disebut. Di samping itu, bentuk perbezaan ini juga berkemungkinan dipengaruhi oleh pertuturan kaum Melayu. Hal ini kerana sungguhpun masyarakat Duano mempunyai penempatan dalam tanah rizab tersendiri, namun kawasan tersebut dikelilingi dengan kampung masyarakat Melayu yang akan menghasilkan komunikasi antara kedua-dua komuniti tersebut. Seterusnya, kesejajaran fonem /o/ dan /u/ boleh berlaku dalam lingkungan suku kata pertama [KV-] dan suku kata akhir dalam struktur [-KVK]. Berikut merupakan antara contohnya:

Jadual 7: Kesejajaran Vokal /o/ : /u/

\begin{tabular}{|c|c|}
\hline Bahasa Duano & BMS \\
\hline /sodep/ & sudip \\
/golu/ & gula \\
/boncit/ & buncit \\
/guyoh/ & guruh \\
/kapo?/ & kampung \\
\hline
\end{tabular}

Bentuk kesejajaran fonem /o/ dan /u/ bahasa Duano juga didapati mempunyai persamaan dengan beberapa dialek Melayu seperti dialek Melaka, dialek Johor, dialek Selangor, dialek Pahang dan dialek Negeri Sembilan (Rujuk contoh menerusi Asmah Haji 
Omar, 2008). Dialek-dialek tersebut cenderung untuk menggantikan fonem /u/ kepada fonem yang lebih luas, iaitu fonem /o/, terutamanya pada lingkungan suku kata akhir struktur [-KVK].

\section{iv) Kesejajaran Vokal /i/ : /u/}

Penelitian menunjukkan vokal /i/ bahasa Duano adalah bersejajaran dengan vokal /u/ bahasa Melayu. Walau bagaimanapun, bentuk perbezaan ini agak terhad jumlahnya. Kesejajaran vokal /i/ dan /u/ memperlihatkan penggantian ciri distingtif dari ciri vokal depan kepada vokal belakang. Gejala ini berlaku dalam lingkungan suku kata pertama dan suku kata akhir struktur [-KV]. Sila perhatikan antara contoh berikut:

Jadual 8: Contoh Kesejajaran Vokal /i/ : /u/

\begin{tabular}{|c|c|}
\hline Bahasa Duano & BMS \\
\hline /i/ & /u/ \\
+depan & + belakang \\
+sempit & + sempit \\
& \\
/munum/ & minum \\
/uyup/ & hirup \\
/gəmbiyu/ & gembira \\
\hline
\end{tabular}

\section{b) Kesejajaran konsonan}

Kesejajaran konsonan merupakan penggantian suatu titik artikulasi fonem konsonan kepada fonem konsonan yang lain. Hasil penelitian menunjukkan kesejajaran konsonan antara bahasa Duano dan BMS boleh berlaku pada lingkungan awal dan akhir kata sahaja Walau bagaimanapun, kesejajaran konsonan yang berlaku pada lingkungan awal kata agak terhad. Terdapat empat bentuk kesejajaran konsonan antara bahasa Duano dan BMS, iaitu:

Jadual 9: Kesejajaran Konsonan Bahasa Duano dan Bahasa Melayu

\begin{tabular}{|l|l|}
\hline Bahasa Duano & BMS \\
\hline$/ \mathrm{\gamma} /$ & $/ \mathrm{r} /$ \\
\hline$/ \mathrm{\gamma} /$ & $/ \mathrm{h} /$ \\
\hline$/ \mathrm{\gamma} /$ & \\
\hline$/ \mathrm{\gamma} /$ & $/ \mathrm{k} /$ \\
\hline
\end{tabular}

i) Kesejajaran Konsonan $/ \mathrm{\gamma} /: / \mathbf{r} /$

Konsonan / $/$ / bahasa Duano adalah bersejajaran dengan konsonan /r/ BMS. Hal ini kerana fonem $/ \mathrm{y} /$ merupakan fonem umum bahasa Duano yang menggantikan posisi konsonan /r/ 
yang tidak wujud dalam bahasa Duano. Menurut Asmah Haji Omar (2008, p. 438), daripada segi rekonstruksi, fonem konsonan $/ \mathrm{\gamma} /$ dan $/ \mathrm{r} /$ adalah bertaraf alofon yang diturunkan daripada induk yang sama, /R/. Kedua-dua fonem tersebut hanya berbeza bentuk namun tidak membezakan makna. Fonem konsonan $/ \mathrm{y} /$ bahasa Duano adalah bersejajaran dalam lingkungan awal dan tengah kata dengan konsonan /r/ BMS. Kesejajaran tersebut juga memperlihatkan perubahan ciri distingtif, iaitu:

Jadual 10: Contoh Kesejajaran Konsonan / $/$ / : /r/

\begin{tabular}{|c|c|}
\hline Bahasa Duano & BMS \\
\hline /y/ & $/ \mathrm{r} /$ \\
+ frikatif & + tril \\
+ velar & + alveolar \\
& \\
/yumput/ & rumput \\
/yotan/ & rotan \\
/yagu/ & raga \\
/koyo/ & kera \\
/gayup/ & garam \\
/koyo/ & kera \\
\hline
\end{tabular}

Bagi bahasa Melayu dan dialek-dialek Melayu yang lain, fonem /r/ terbahagi kepada tiga variasi, iaitu konsonan tril alveolar $/ \mathrm{r} /$, konsonan frikatif velar $/ \mathrm{P} / \mathrm{dan}$ konsonan frikatif uvular $/ \mathrm{S} /$.

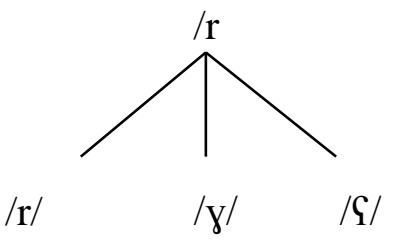

Rajah 1: Senarai Alofon Fonem /r/ BMS dan Dialek-dialek Melayu

Ketiga-tiga fonem tersebut berbeza penggunaannya berdasarkan faktor situasi dan geografi. Konsonan /r/ digunakan di Semenanjung Malaysia, Sarawak dan Brunei dalam situasi-situasi formal sahaja. Konsonan $/ \mathrm{\gamma} /$ pula merupakan variasi yang paling dominan memandangkan variasi ini digunakan di kebanyakan kawasan di Malaysia, terutamanya bagi dialek-dialek di kawasan selatan dan pantai timur Semenanjung Malaysia serta bahasa di Sarawak dan Urak Lawoi" (Asmah Haji Omar, 1995, p. 94). Variasi / $/$ / tersebut mempunyai persamaan dengan bentuk yang digunakan dalam bahasa Duano. Selain itu, fonem frikatif uvular pula hanya wujud di kawasan utara, misalnya dalam dialek Kedah dan dialek Parit. Jadi, sungguhpun bahasa Melayu tidak mempunyai fonem $/ \mathrm{y} /$ sebagai fonem umum, namun fonem tersebut masih mempunyai penyebaran yang luas dalam dialek-dialek Melayu yang lain. Gejala tersebut menunjukkan bahawa bahasa Duano dan bahasa Melayu masih mempunyai perkaitan yang rapat.

\section{i) Kesejajaran Konsonan $/ \mathbf{2} /: / \mathbf{h} /$}

Kesejajaran konsonan antara bahasa Duano dan BMS juga dapat dilihat menerusi padanan konsonan / $\mathrm{P}: \mathrm{h} /$. Walau bagaimanapun, bentuk perbezaan ini tidak berlaku 
secara dominan dalam bahasa Duano. Kesejajaran konsonan / $/$ / bahasa Duano dan /h/ BMS berlaku dalam lingkungan akhir kata sahaja. Kesejajaran ini turut memperlihatkan perbezaan ciri distingtif, iaitu ciri [+plosif +glotis konsonan] /?/ kepada ciri [+frikatif + glotis] konsonan /h/. Sila perhatikan antara contoh berikut:

Jadual 11: Contoh Kesejajaran Konsonan / / : /h/

\begin{tabular}{|c|c|}
\hline Bahasa Duano & BMS \\
/bəsa?/ & basah \\
/bua?/ & buah \\
/bula?/ & buluh \\
/pata?/ & patah \\
\hline
\end{tabular}

\section{ii) Kesejajaran Konsonan $/ \mathrm{y} /:$ /k/}

Kesejajaran antara fonem konsonan $/ \mathrm{\gamma} /$ bahasa Duano dan konsonan /k/ BMS pula berlaku dalam lingkungan awal dan tengah kata sahaja. Bentuk inovasi ini juga tidak berlaku secara meluas dalam kata berkognat bahasa Duano dan BMS. Berikut merupakan contoh-contohnya:

Jadual 12: Contoh Kesejajaran Konsonan / / / : /k/

\begin{tabular}{|c|c|}
\hline Bahasa Duano & BMS \\
\hline$/ \mathrm{y} /$ & $/ \mathrm{k} /$ \\
+ frikatif & + plosif \\
+ velar & + alveolar \\
& \\
/yapal/ & kapal \\
/yoyu/ & kayu \\
/təmayaw/ & tembakau \\
/aya/ & akar \\
\hline
\end{tabular}

\section{iii) Kesejajaran Konsonan $/ \mathrm{y} /: / \mathrm{h} /$}

Hasil penelitian turut menunjukkan bahawa wujud kesejajaran antara konsonan frikatif velar $/ \mathrm{\gamma} /$ bahasa Duano dengan konsonan frikatif glotis $/ \mathrm{h} / \mathrm{BMS}$. Kesejajaran tersebut boleh dilihat pada lingkungan awal dan tengah kata. Walau bagaimanapun, kesejajaran tersebut tidaklah berlaku secara meluas namun hanya dapat dilihat menerusi beberapa contoh perkataan sahaja. Kelainan tersebut mungkin sahaja wujud berdasarkan penyebutan informan itu sendiri. Berikut merupakan contohnya:

$\begin{array}{cc}\text { Bahasa Duano } & \text { BMS } \\ \text { 1. /pəуə/ } & \text { peha } \\ \text { 2. /bəуu/ } & \text { bahu }\end{array}$




\section{Penyahnasalan}

Penyahnasalan merupakan proses penggantian bunyi nasal kepada bunyi oral yang mempunyai ciri homorgan (Rohani Mohd Yusof, 2016, p. 96). Tambahnya, proses fonologi ini turut berlaku dalam bahasa Austronesia lain, khususnya bahasa Melayu Urak Lawoi'. Hasil penelitian menunjukkan proses penyahnasalan dalam bahasa Duano berlaku dalam lingkungan akhir kata sahaja. Fonem oral yang bersejajaran pula merupakan fonem konsonan plosif tak bersuara. Fonem nasal BMS akan digantikan dengan fonem oral yang homorgan dalam bahasa Duano. Walau bagaimanapun, penggantian fonem tersebut masih memperlihatkan perkongsian titik artikulasi yang serupa. Sila perhatikan rajah berikut:

Jadual 13: Contoh Proses Penyahnasalan Bahasa Duano dan BMS

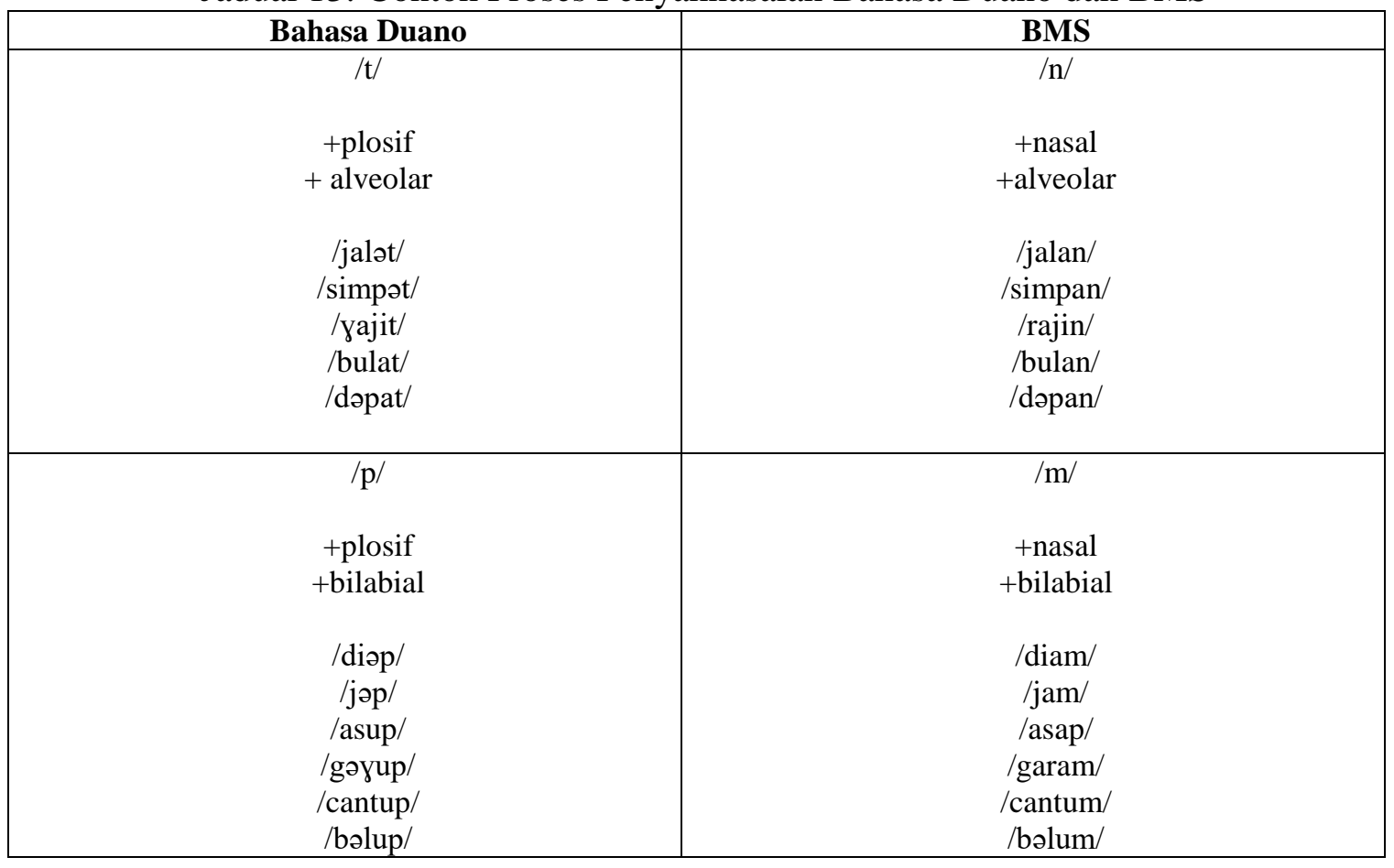

\section{Pengglotisan}

Pengglotisan merupakan proses yang memperlihatkan kewujudan fonem / $/$ / dalam perkataan sama ada secara penambahan atau penggantian. Menurut Rohani Mohd Yusof (1999), proses pengglotisan yang wujud dalam bahasa Melayu-Proto terbahagi kepada dua jenis, iaitu sebagai pengganti dan penambah. Hasil penelitian menunjukkan bahawa proses pengglotisan bahasa Duano terbentuk melalui kaedah pengganti dan penambah.

Proses pengglotisan sebagai pengganti berlaku apabila suatu fonem lain dalam perkataan digantikan dengan fonem / $/$ yang memperlihatkan perbezaan ciri distingtif. Penelitian menunjukkan rata-rata perkataan berkognat BM standard yang diakhiri dengan fonem /y/ akan digantikan dengan fonem / $/$ / dalam bahasa Duano. Sila perhatikan contohcontoh berikut: 
Jadual 14: Contoh Proses Pengglotisan secara Penggantian Bahasa Duano dan BMS

\begin{tabular}{|c|c|}
\hline Bahasa Duano & BMS \\
\hline$/$ ?/ & $/ \mathrm{y} /$ \\
$/$ sabo?/ & sabung \\
$/$ luba?/ & lubang \\
$/$ caba?/ & cabang \\
$/$ ula?/ & ulang \\
$/$ mondo?/ & mendung \\
$/$ subə?/ & subang \\
\hline
\end{tabular}

Proses pengglotisan secara penambah pula berlaku apabila sesuatu perkataan ditambahkan dengan ciri glotis [+glotis]. Penelitian menunjukkan bahawa pengglotisan penambah dalam bahasa Duano hanya wujud dalam lingkungan akhir kata sahaja dan kewujudannya amat terhad.

Jadual 15: Contoh Proses Pengglotisan secara Penambah Bahasa Duano dan BMS

\begin{tabular}{|c|c|}
\hline Bahasa Duano & BMS \\
/-KV/ & /-KV?/ \\
/juta?/ & juta \\
/udə?/ & ada \\
/cuco?/ & cucu \\
\hline
\end{tabular}

\section{Perangkapan}

Perangkapan merupakan gabungan dua atau lebih fonem segmental, iaitu fonem vokal atau konsonan secara berurutan (Asmah Haji Omar, 1995, p. 35). Proses perangkapan akan menghasilkan rangkap vokal dan rangkap konsonan (Rohani Mohd Yusof, 2016, p. 98).

\section{a) Rangkap vokal}

Menurut Rohani Mohd Yusof (2016, p. 99), rangkap vokal boleh wujud melalui dua cara, iaitu dengan menggugurkan fonem konsonan yang terletak di antara fonem vokal dan penambahan vokal kepada fonem vokal sedia ada. Penelitian terhadap data menunjukkan bahawa proses perangkapan vokal yang berlaku dalam bahasa Duano terdiri daripada kedua- dua cara tersebut. Perangkapan melalui cara pertama, iaitu dengan menggugurkan fonem konsonan hanya berlaku dalam lingkungan tengah kata sahaja. Fonem konsonan dalam struktur /-VKV/ akan digugurkan dan kemudiannya membentuk rangkap vokal. Walau bagaimanapun, proses perangkapan vokal dengan cara pengguguran fonem konsonan dalam bahasa Duano agak terhad. Data menunjukkan bahawa konsonan $/ \mathrm{h} /$ yang berada di tengah kata bahasa Duano akan digugurkan dan membentuk urutan rangkap fonem. 
Jadual 16: Contoh Proses Perangkapan Vokal dengan Pengguguran Konsonan

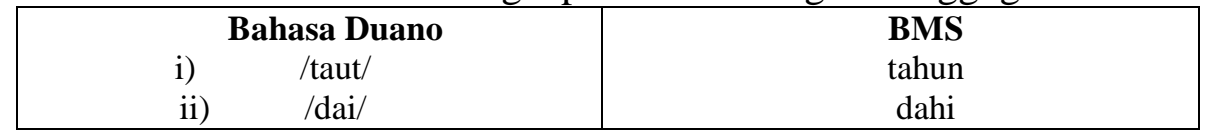

Proses perangkapan kedua adalah melalui penambahan vokal kepada fonem vokal sedia ada. Walau bagaimanapun, rangkap vokal yang terhasil melalui proses ini adalah terhad. Berikut adalah contohnya:

Jadual 17: Contoh Proses Perangkapan Vokal dengan Penambahan Vokal

\begin{tabular}{|c|c|}
\hline Bahasa Duano & BMS \\
/kambia?/ & kambing \\
/yantia?/ & ranting \\
\hline
\end{tabular}

Berdasarkan contoh di atas, dapat dilihat bahawa fonem /a/ ditambahkan selepas vokal /i/ yang menghasilkan rangkap vokal /ia/. Kehadiran fonem /?/ selepas rangkap vokal bukanlah kesan daripada perangkapan tersebut, sebaliknya bentuk berikut merupakan perubahan bunyi seragam yang wujud dalam bahasa Duano, iaitu proses pengglotisan.

\section{b) Rangkap konsonan}

Rangkap konsonan bahasa Duano pula terbentuk melalui cara pengguguran fonem vokal yang terletak di antara fonem konsonan. Proses ini hanya wujud dalam lingkungan awal kata yang terdiri daripada struktur /KVK-/ dan vokal yang menempati posisi tersebut adalah fonem /ə/. Gejala yang serupa juga dapat dilihat menerusi bahasa Melayu Urak Lawoi', iaitu proses perangkapan konsonan hanya berlaku pada lingkungan awal kata dan lazimnya vokal /a/ akan mengalami proses pengguguran (Rohani Mohd Yusof, 2016, p. 100). Berikut merupakan contoh-contoh proses perangkapan bunyi konsonan dalam bahasa Duano:

Jadual 18: Contoh Proses Perangkapan Bunyi Konsonan Bahasa Duano dan BMS
\begin{tabular}{|c|c|}
\hline Bahasa Duano & BMS \\
\hline /KøK-/ & /KVK-/ \\
& \\
/plandu?/ & pelanduk \\
/blalan/ & belalang \\
/bluka/ & belukar \\
/tlunju?/ & telunjuk \\
/slalu/ & selalu \\
\hline
\end{tabular}

\section{Pemonoftongan}

Pemonoftongan merupakan proses yang memperlihatkan penghilangan ciri diftong dalam perkataan melalui cara pemenggalan salah satu unsur diftong atau peleburan bunyi diftong kepada bunyi lain (Rohani Mohd Yusof, 1999). Tambahan lagi, Asmah Omar (1995, p. 38) menyatakan bahawa proses pemonoftongan berlaku melalui dua 
cara, iaitu:

a) Penghilangan geluncuran /w/ dan /y/ tanpa perubahan terhadap kualiti vokal sebelumnya

b) Peleburan ciri-ciri distingtif diftong dan menghasilkan vokal baharu.

Hasil penelitian menunjukkan bahawa proses pemonoftongan yang berlaku dalam bahasa Duano terdiri dalam kelompok (b) sahaja, iaitu bunyi diftong akan dileburkan membentuk fonem baharu. Penelitian terhadap data juga menunjukkan bahawa peleburan diftong akan digantikan dengan fonem vokal baharu yang berbeza ciri distingtif daripada vokal pengisi diftong sebelumnya. Sila perhatikan antara contoh berikut:

Jadual 19: Contoh Proses Pemonoftongan secara Peleburan Bunyi Diftong
\begin{tabular}{|c|c|}
\hline Bahasa Duano & BMS \\
\hline$/$ panti/ & pantai \\
$/$ lambi/ & lambai \\
$/$ paki/ & pakai \\
$/$ kəyəbo/ & kerbau \\
$/$ kalu/ & kalau \\
$/$ sədəyu/ & saudara \\
\hline
\end{tabular}

Selain itu, gejala pemonoftongan juga turut berlaku dalam dialek-dialek Melayu. Antara dialek tersebut ialah dialek Perak, Pahang, Terengganu dan Kelantan (Asmah Haji Omar, 2008). Sebagai contoh, dialek Kelantan tidak mempunyai sistem diftong memandangkan kesemua bunyi diftong akan mengalami proses pemonoftongan secara pemenggalan. Contohnya adalah perkataan /pisaw/ menjadi /pisa/ dan /keday/ menjadi /keda/ (Asmah Omar, 2008, p. 319).

\section{Penghilangan suku kata}

Hasil penelitian menunjukkan bahawa berlakunya proses penghilangan suku kata dalam bahasa Duano. Gejala ini berlaku apabila sesuatu struktur suku kata dihilangkan atau digugurkan dalam sesuatu perkataan yang menyebabkan pemendekan penyebutan (Rohani Mohd Yusof, 1999). Penghilangan suku kata boleh terjadi dalam semua lingkungan kata, iaitu pada awal, tengah dan akhir kata. Sila perhatikan antara contoh berikut:

Jadual 20: Contoh Proses Penghilangan Suku Kata

\begin{tabular}{|c|c|}
\hline Bahasa Duano & BMS \\
\hline /lay/ & helai \\
/yuan/ & haruan \\
/səsəmu/ & selesema \\
/yimaw/ & harimau \\
/bəh/ & bawah \\
\hline
\end{tabular}


Berdasarkan contoh-contoh di atas, penghilangan suku kata kebanyakannya akan menghasilkan kata akar yang terdiri daripada dua suku kata. Kata-kata yang berbentuk satu suku kata amat terhad jumlahnya dan buktinya dapat dilihat menerusi contoh data di atas. Bentuk ini sedikit sebanyak memperlihatkan kesejajaran dengan bahasa Melayu kerana perkataan bahasa Melayu kebanyakannya terdiri daripada dua suku kata (Noor Azlina Zaidan, Mohd Zaki bin Abd Rahman dan Muhammad Azhar Zailaini, 2018). Menurut Rohani Mohd Yusof (2016, p. 109), perkataan yang terdiri daripada dua suku kata merupakan bentuk umum bahasa-bahasa Austronesia. Gejala ini juga dapat dilihat menerusi bahasa Melayu Urak Lawoi', iaitu penghilangan suku kata yang mewujudkan perkataan dwisuku (Rujuk contoh menerusi Rohani Mohd Yusof, 2016).

\section{Peleburan fonem}

Hasil penelitian menunjukkan bahawa wujudnya proses peleburan fonem dalam bahasa Duano. Menurut Asmah Haji Omar (1995, p. 46), peleburan fonem merupakan gejala peleburan dua fonem menjadi satu. Tambahan lagi, peleburan fonem ialah proses yang lazim berlaku dalam bahasa-bahasa Austronesia, terutamanya dalam lingkungan tengah dan akhir kata (Rohani Mohd Yusof, 2016, p. 167).

Walau bagaimanapun, penelitian terhadap bahasa Duano menunjukkan proses peleburan fonem hanya berlaku dalam lingkungan akhir perkataan sahaja. Tambahan pula, rata-rata urutan fonem yang mengalami peleburan adalah urutan vokal yang diikuti dengan fonem/r/. Hal ini adalah kerana fonem $/ \mathrm{r} /$ tidak wujud dalam bahasa Duano dan hanya bersejajaran dengan fonem $/ \mathrm{\gamma} /$. Jadi, kata berkognat BM standard yang diakhiri dengan fonem $/ \mathrm{r} /$ akan mengalami pengguguran atau peleburan dalam bahasa Duano. Berikut adalah contohnya:

\section{Jadual 21: Contoh Proses Peleburan Fonem Bahasa Duano dan BMS}

\begin{tabular}{|c|c|}
\hline Bahasa Duano & BMS \\
\hline /-e/ & /-ir/ \\
& \\
/uke/ & ukir \\
$/$ cae/ & cair \\
$/$ bane/ & banir \\
\hline /-o/ & /-ar/ \\
/lapə/ & lapar \\
$/$ tampo/ & tampar \\
/kasə/ & kasar \\
\hline /-o/ & /-ur/ \\
& \\
/uko/ & ukur \\
/cuko/ & cukur \\
$/$ lumpo/ & lumpur \\
\hline
\end{tabular}

Berdasarkan contoh-contoh di atas, didapati bahawa proses peleburan fonem hanya berlaku apabila urutan /-ir/, /-ər/ dan /-ur/ berada dalam lingkungan akhir perkataan sahaja. 
Kesemua urutan fonem tersebut akan dileburkan menjadi suatu vokal baharu yang mempunyai ciri distingtif berbeza.

\section{Metatesis}

Hasil penelitian menunjukkan bahawa proses metatesis turut berlaku dalam bahasa Duano. Menurut Rohani Mohd Yusof (1999), metatesis ialah proses perubahan bunyi yang melibatkan pertukaran tempat antara dua bunyi, rentetan bunyi atau suku kata. Walau bagaimanapun, proses ini tidak begitu dominan dalam bahasa Duano dan contoh-contoh yang diperoleh juga agak terhad. Sila perhatikan antara contoh berikut:

Jadual 22: Contoh Proses Metatesis Bahasa Duano dan BMS

\begin{tabular}{|c|c|}
\hline Bahasa Duano & BMS \\
\hline /muysa?/ & musang \\
/binis/ & bising \\
/sanu/ & sungai \\
/lomayi/ & almari \\
\hline
\end{tabular}

Berdasarkan contoh di atas, perkataan /muysa?/ dan /bijis/ memperlihatkan perubahan posisi fonem / $\mathrm{y} /$ dari kedudukan akhir kata kepada posisi suku kata awal perkataan. Bagi perkataan /sanu/ pula, boleh dikatakan bahawa perkataan tersebut melalui proses pemonoftongan terlebih dahulu dan kemudian posisi fonem /u/ dan /a/ saling berubah kedudukan. Perkataan /ləmayi/ pula memperlihatkan perubahan pada struktur suku kata pertama, iaitu suku kata /al-/ digantikan dengan /lə-/ yang turut mengalami proses penggantian fonem vokal sejajar.

\section{Kesimpulan}

Perbezaan fonologi yang berlaku dalam bahasa Duano membuktikan bahawa bahasa ini telah berkembang secara sendirian dan terasing daripada BMS sungguhpun kedua-duanya berkongsi "ibu" yang sama. Penelitian terhadap kata berkognat menunjukkan bahawa bahasa Duano telah berinovasi dan membentuk ciri fonologi tertentu yang berbeza dengan BMS, namun bentuk-bentuk perbezaan tersebut masih memperlihatkan kesejajaran. Di samping itu, penelitian terhadap ciri bunyi bahasa Duano turut memperlihatkan perkaitan dengan dialek-dialek Melayu dan bahasa-bahasa Austronesia yang lain, misalnya bahasa Melayu Urak Lawoi' '. Kesejajaran tersebut juga sedikit sebanyak memperlihatkan bahawa kelainan-kelainan tersebut masih berkongsi dan mengekalkan ciri induk yang diwarisi bersama. Perbezaan dan perubahan bunyi bahasa Duano boleh wujud pada unsur vokal mahupun konsonan dalam semua lingkungan perkataan. Antara bentuk perbezaan bunyi yang paling ketara dan dominan kewujudannya dalam bahasa Duano ialah proses kesejajaran fonem vokal / $/ \mathrm{a}: \mathrm{a}$, kesejajaran fonem konsonan $/ \mathrm{\gamma}: \mathrm{r} /$ dan proses pengglotisan. Ketiga-tiga proses tersebut seakan menjadi identiti fonologi bahasa Duano yang membezakan secara jelas bahasa Duano dengan bahasa-bahasa keluarga lain, terutamanya BMS. Hasil penelitian juga menunjukkan bahawa wujud proses perubahan bahasa secara bertumpang-tindih dalam bahasa Duano. Hal ini memperlihatkan kewujudan beberapa proses fonologi secara serentak dalam sesuatu perkataan. 
Kesimpulannya, perubahan bunyi yang berlaku dalam bahasa Duano ialah hasil inovasi yang wujud sepanjang tempoh perkembangan secara bersendirian dalam kawasan dan komunitinya yang tersendiri. Sungguhpun kajian menunjukkan kehidupan masyarakat Duano sentiasa dikelilingi oleh masyarakat Melayu sama ada dari segi penempatan mahupun kegiatan ekonomi, faktor tersebut tidak mampu membendung bahasa Duano daripada berkembang sendirian tanpa pengaruh bahasa Melayu standard.

\section{Rujukan}

Ab. Razak Ab. Karim \& Muhammad Saiful Haq Hussin. (2011). Tahap penguasaan bahasa Melayu di Islamic Sant/ Tham Foundation School (ISFS). Jurnal Pengajian Melayu / Journal of Malay Studies (JOMAS), 22(1), pp. 18-44.

Andaya, L.Y. (1987). The Kingdom of Johor 1641-1728. Terj. Shamsuddin Jaafar. Kuala Lumpur: Dewan Bahasa dan Pustaka.

Asmah Haji Omar. (1983). The Malay peoples of Malaysia and their languages. Kuala Lumpur: Dewan Bahasa dan Pustaka.

Asmah Haji Omar. (1991). Aspek bahasa dan kajiannya: Kumpulan Siri Ceramah Peristilahan. Kuala Lumpur: Dewan Bahasa dan Pustaka.

Asmah Haji Omar. (1995). Rekonstruksi fonologi bahasa Melayu induk. Kuala Lumpur: Dewan Bahasa dan Pustaka.

Asmah Haji Omar. (200)1. Kaedah penyelidikan bahasa di lapangan. Kuala Lumpur: Dewan Bahasa dan Pustaka.

Asmah Haji Omar. (2001). Language and language situation of Southeast Asia. Journal of Modern Languages, 13(1), pp. 1-17.

Asmah Haji Omar. (2003). Language and language situation in South East: With a Focus on Malaysia. Kuala Lumpur: Akademi Pengajian Melayu.

Asmah Haji Omar. (2008). Susur galur bahasa Melayu. Kuala Lumpur: Dewan Bahasa dan Pustaka.

Asmah Haji Omar, Samsur Rijal Yahya \& Noor Hasnoor Mohamad Nor. (2018). The Orang Asli of Malaysia: A linguistic perspective. Kuala Lumpur: Dewan Bahasa dan Pustaka.

Eberhard, David M., Gary F. Simons \& Charles D. Fennig (eds.). (2021). Ethnologue: Languages of the world. Twenty-fourth edition. Dallas, Texas: SIL International. Retrieved from http://www.ethnologue.com.

Habibah Abdul Jabbar, Nor Azlin Hamidon, Muhammad Ismail Ab Kadir \& Abdul Razak Abdul Jabbar. (2019). Kain Tenun Pahang dan Kain Tenun Sulawesi: Satu kajian perbandingan awal. Jurnal Pengajian Melayu / Journal of Malay Studies (JOMAS). 30 (1), pp. 53-70. 
Herbert Schendl \& H. G. Widdowson. (2001). Historical linguistics. Great Clarendon Street, Oxford: Oxford University Press.

Leonard Bloomfield. (1963). Language. Delhi: Motilal Banarsidass Indological Publishers \& Booksellers.

Mohd Sharifudin Yusop. (2013). Keterancaman bahasa Orang Asli Duano dan Kanaq. Serdang: Universiti Putra Malaysia.

Mohd Tarmizi Hasrah, Shahidi A.H \& Rahim Aman. (2013). Inovasi dan Retensi dalam Dialek Hulu Tembeling. Gema Online Journal of Language Studies. 13(3). Retrieved from https://ejournal.ukm.my/gema/article/view/4230/2347.

Najjah Salwa Abd Razak \& Wan Norhasniah Haji Wan Hussin. (2011). Hubungan sosial antara komuniti Melayu dan komuniti bukan Melayu mengikut perspektif peradaban: Satu pengenalan. Jurnal Pengajian Melayu / Journal of Malay Studies (JOMAS), 22(1), pp. 205-233.

Noor Azlina Zaidan, Mohd Zaki Abd Rahman \& Muhammad Azhar Zailaini. (2018). Analisis kata serapan bahasa Arab berdasarkan pembentukan kata bahasa Melayu. Jurnal Pengajian Melayu / Journal of Malay Studies (JOMAS), 29(1), pp. 78101.

Norazila Alias. (1986). Dialek Kuala Pilah: Satu tinjauan fonologi dan leksikal. Kuala Lumpur: Jabatan Pengajian Melayu Universiti Malaya.

Noriah Mohamed. (1996). Konsep kekeluargaan bahasa dan kaedah perbandingan dalam linguistik sejarah dan perbandingan. Jurnal Dewan Bahasa. 40(2), pp. 128-138.

Noriah Mohamed. (1999). Waktu pisah dan tingkat kekerabatan bahasa Melayu dengan bahasa Iban. Jurnal Dewan Bahasa, 38(2), pp. 129-143.

Nur Hidayah Mohamed Suleiman. (2015). Struktur Frasa Bahasa Orang Asli Duano. Kuala Lumpur: Akademi Pengajian Melayu, Universiti Malaya.

R. L. Trask. (1996). Historical Linguistics. London: Arnold.

Rohani Mohd Yusof. (1986). Dialek Kuala Kangsar: Satu Kajian Perbandingan Fonologi. Tesis Sarjana. Jabatan Pengajian Melayu, Universiti Malaya.

Rohani Mohd Yusof. (1999). Perbandingan Morfologi Bahasa Melayu dan Bahasa Iban. Disertasi Ijazah Doktor Falsafah. Jabatan Pengajian Melayu, Universiti Malaya.

Rohani Mohd Yusof \& Nur Hidayah Mohamed Suleiman. (2014). Sistem bilangan dalam bahasa Orang Asli Duano. Jurnal Bahasa, 14(4), pp. 45-49.

Rohani Mohd Yusof. (2016) Bahasa Melayu Urak Lawoi’. Kuala Lumpur: Dewan Bahasa dan Pustaka.

Rohani Mohd Yusof \& Noor Hasnoor Mohd Nor. (2014). "Bahasa orang asli Melayuproto: Bahasa atau dialek Melayu?". Persidangan Serantau Kearifan Tempatan 2014 (RCLK 4): Sinergi Kelestarian Dinamisme, 11-14 Oct 2014. Kuching: Sarawak. 
Jabatan Kemajuan Orang Asli (JAKOA). (2018). Retrieved from https://www.jakoa.gov.my/.

Sopher, D. E. (1965). “The Sea Nomads”. Kuala Lumpur: National Museum.

Yuszaidy Mohd Yusoff, Mohamad Nazri Ahmad \& Mohamed Anwar Omar Din. (2009). Laporan kajian warisan Orang Kuala: Kajian kes di Batu Pahat dan Pontian, Johor. Jurnal Melayu, 4 (2009), pp. 143-160. 